\title{
Transcription Factor AP-2-Alpha
}

National Cancer Institute

\section{Source}

National Cancer Institute. Transcription Factor AP-2-Alpha. NCI Thesaurus. Code C17294.

Transcription factor AP-2-alpha (437 aa, $\sim 48 \mathrm{kDa}$ ) is encoded by the human TFAP2A gene. This protein plays a role in both transcriptional regulation and lens vesicle morphogenesis. 